\title{
EIF3K wt Allele
}

National Cancer Institute

\section{Source}

National Cancer Institute. EIF3K wt Allele. NCI Thesaurus. Code C114630.

Human EIF3K wild-type allele is located in the vicinity of 19q13.2 and is approximately 18 $\mathrm{kb}$ in length. This allele, which encodes eukaryotic translation initiation factor 3 subunit $\mathrm{K}$ protein, plays a role in the initiation of protein synthesis. 